\title{
FACTORS RELATED OF DIABETES MELLITUS TYPE II IN KEBON JERUK DISTRICT
}

\author{
Devi Angeliana Kusumaningtiar, Nur'Aulia Baharuddin \\ Department of Public Health, Faculty of Health Sciences, Universitas Esa Unggul, Jakarta, 11510, Indonesia
}

\begin{abstract}
Diabetes mellitus is a condition that increases blood sugar levels that are chronic as a result of a disruption of body metabolisms such as fat, carbohydrate, and protein due to a deficiency of the hormone insulin. The main problem in people with DM is the occurrence of complications, especially the complications of chronic $D M$, which is the main cause of morbidity and mortality in DM patients. This study aims to analyze relationship between family history, age, gender, physical activity, obesity, hypertension to the incidence of Diabetes Mellitus type II. This research is a quantitative research type and uses a cross-sectional design. This research was conducted at the Kebon Jeruk District Health Center in West Jakarta in 2018, with a sample size of 77 samples or respondents. Independent variables included family history, age, gender, physical activity, obesity, and hypertension. The dependent variable is type II diabetes mellitus. Analysis of the relationship between the two variables was measured using the chi-square test. The results showed an association between life history, age, physical activity, and obesity with the incidence of type II DM in Kebon Jeruk District Health Center in 2018. It is recommended that people who have a family history of DM to immediately detect DM disease and apply a healthy lifestyle, carry out physical activities for at least 15-20 minutes every day, health workers are also advised to continue to conduct health education related to DM disease.
\end{abstract}

Keywords: Diabetes mellitus, risk factor

\begin{abstract}
ABSTRAK
Diabetes melitus merupakan masalah kesehatan yang terjadi akibat suatu peningkatan kadar gula darah yang kronik, hasil dari proses metabolisme karbohidrat, lemak, dan protein yang terganggu karena kekurangan hormon insulin. Penderita diabetes melitus sering mengalami komplikasi, yang merupakan penyebab utama kesakitan dan kematian penderita diabetes melitus. Penelitian ini bertujuan untuk menganalisis hubungan riwayat keluarga, umur, jenis kelamin, aktivitas fisik, obesitas, hipertensi dengan kejadian Diabetes Mellitus tipe II. Penelitian ini merupakan penelitian kuantitatif dengan desain cross sectional. Penelitian ini dilakukan di Puskesmas Kecamatan Kebon Jeruk Jakarta Barat pada tahun 2018, dengan besaran sampel sebanyak 77 sampel atau responden. Variabel bebas meliputi riwayat keluarga, jenis kelamin, usia, obesitas, aktivitas fisik serta hipertensi. Variabel terikat adalah diabetes mellitus tipe II. Analisi hubungan antara dua variabel diukur menggunakan uji chi square. Berdasarkan uji statistic menyatakan bahwa ada hubungan riwayat keluarga $p$ value 0,000 , usia $p$ value 0,008 , aktivitas fisik $p$ value 0,000 , serta obesitas dengan kejadian diabetes melitus tipe II di Puskesmas Kecamatan Kebon Jeruk tahun 2018. Disarankan agar masyarakat yang memiliki riwayat keluarga diabetes melitus untuk segera melakukan deteksi dini terhadap penyakit diabetes melitus serta menerapkan pola hidup sehat, melakukan aktivitas fisik setidaknya 15-20 menit setiap harinya, petugas kesehatan pun disarankan untuk terus melakukan penyuluhan kesehatan terkait penyakit diabetes melitus. Adanya komitmen dokter untuk memulai praktek sesuai dengan jadwal agar pasien tidak menunggu dengan waktu lama.
\end{abstract}

Kata Kunci : Diabetes mellitus, faktor risiko

Correspondece Address: Devi Angeliana Kusumaningtiar, Department of Public Health, Faculty of Health Sciences, Universitas Esa Unggul, Jakarta, 11510, Indonesia, E-mail : deviangeliana@esaunggul.ac.id 


\section{Introduction}

Diabetes Mellitus (DM) is a disease of metabolic disorder, especially carbohydrate metabolism, caused by the decrease or absence of insulin hormones from the beta cells of the pancreas, or due to impaired insulin function, or both. ${ }^{1}$ Type 2 Diabetes is the most common condition and serious global health problem. ${ }^{2}$ The high prevalence of type 2 diabetes is caused by interactions between genetic vulnerability factors and environmental exposure. ${ }^{3}$ Research that has been done previously mentioned that the risk factors of type $2 \mathrm{DM}$ events are age, ethnicity, gender, genetic, hypertension, BMI, body fat distribution, diet, physical activity, cholesterol levels, stress. $^{4}$

According to the World Health Organisation (WHO), an estimated 347 million people and more than $80 \%$ of the deaths from DM in the world suffer from diabetes mellitus, and if this continues to be left without the prevention certainly the number of sufferers DM can increase. ${ }^{5}$ Based on the results of ${ }^{6}$ where DKI Jakarta is the second most province with the prevalence of Diabetes Mellitus, amounting to 2.5\% after Yogyakarta (2.6\%). Riskesdas 2018 indicates the prevalence of untransmitted diseases increased compared with Riskesdas 2013, among others, cancer, stroke, chronic kidney disease, diabetes mellitus, and hypertension. Based on blood glucose screening, diabetes mellitus rises from $6.9 \%$ to $8.5 \%$; blood pressure measurement results, hypertension increased from $25.8 \%$ to $34.1 \%{ }^{7}$

Based on the health profile of Kebon Jeruk the data obtained occurred increased cases of DM type II as much as $2.33 \%$ from 2016 to 2017 , wherein 2016 showed the prevalence of type II DM cases of $5.17 \%$ or as many as 8,626 cases of Diabetes Mellitus type II, then the prevalence of case type II DM increased in 2017 to $7.50 \%$ or 12,261 cases of Diabetes Mellitus type II. In January The month of August 2018 reported the prevalence of type II DM cases as much as $4.15 \%$ or there are 6,087 cases of Diabetes Mellitus type II and expected to continue to increase. ${ }^{8}$

Based on the data obtained, there are $4.15 \%$ cases of type II DM in the year 2018, where the well-managed type II DM will have an impact of about $70 \%$, causing various chronic complications. Still, the high disease Diabetes Mellitus (DM) type II be a special concern by health worker District primary health care in Kebon Jeruk because the disease type II DM is a disease called The Great Imitator. After all, this disease all organs and inflict various kinds of complaints or complications. This study aims to analyze the relationship between family history, age, gender, physical activity, obesity, hypertension to the incidence of Diabetes Mellitus type II in Kebon Jeruk District primary health care. 


\section{Method}

This research is a quantitative research type and uses a cross-sectional design. The sample in this research is the patient at Kebon Jeruk District. The sampling technique used is a systematic random sampling, which is sampling with a certain interval of a predetermined sample skeleton. The Interval obtained is 2 . Then, sampling done by the researchers ranging from the patient/sample visit 2nd, 4, 6, and so on so obtained 77 samples with the sample calculation uses the formula 2 proportions. The Obesity variable is measured by data collection, which is used is to ask the respondent's height and weight, which will then be calculated BMI and hypertension variable it was measured using the respondent's medical record data, Family history, age, and gender using a questionnaire, then Physical activity was measured using the Riskesdas questionnaire with 9 questions, to ask whether you had ever done heavy or moderate physical activity that was done continuously for 10 minutes or more, and how many days was it done in 1 week. Inclusion criteria characteristics of respondents who have Type II diabetes mellitus and who have checked themselves in Kebon Jeruk District primary of health care. Exclusion criteria were respondents, who were not willing to be the research sample. The results of this study were analyzed by using Chi-Square. Ethical clearance 0603-18.602/DPKE-KEP/FINALEA/UEU/XII/2018.

\section{Results}

Table 1. The frequency distribution Status of Diabetes Mellitus type II, family history, age, gender, physical activity, obesity, and hypertension in the village Village District Kebon Jeruk

\begin{tabular}{lcc}
\hline \multicolumn{1}{c}{ Variable } & Total & Percent \\
\hline Status DM type II & 54 & \\
DM type II & 23 & $70.1 \%$ \\
Non-DM type II & & $29.9 \%$ \\
Family History & 54 & \\
Yes & 23 & $70.1 \%$ \\
No & & $29.9 \%$ \\
Age & 46 & $59.7 \%$ \\
At Risk, if > 40 years old & 31 & $40.3 \%$ \\
No Risk, if $\leq 40$ years old & & \\
Gender & 22 & $28.6 \%$ \\
Male & 55 & $71.4 \%$ \\
Female & & \\
Physical Activity & 51 & $56.2 \%$ \\
Less, if < 150 minutes for 5 days in 1 week & 26 & $33.8 \%$ \\
$\quad$ Enough, if $\geq 150$ minutes for 5 days in 1 week & & $57.1 \%$ \\
Obesity & 44 & $42,9 \%$ \\
$\quad$ Obesity & 33 & $39,0 \%$ \\
$\quad$ Normal & & $60,0 \%$ \\
Hypertension & 30 & \\
Hypertension & 47 & \\
Non - Hypertension &
\end{tabular}


The results to table 1, from the research result of 77 respondents, it was obtained that the proportion of the status of the highest type II DM is with a category of DM type II as much as 54 people $(70.1 \%)$, while the proportion of the status of DM type II is the lowest with a Non-DM type II category of 23 people (29.9\%). The proportion of the highest family history of the category is a family history of type II DM as much as 54 people (70.1\%). The proportion of the highest age is with the age category at risk as much as 46 people (59.7\%). The proportion of genders is the highest of females,with a total of 55 people $(71.4 \%)$. The proportion of the highest physical activity is the physical activity category of approximately 51 people (56.2\%). The proportion of obesity is the highest with the category of obesity/overweight as much as 44 people $(57.1 \%)$. The highest proportion of hypertension is the category of not hypertension as much as 47 people $(60.0 \%)$.

\section{Bivariate Analysis}

Table 2 Association between Family history relations, age, gender, physical activity, obesity, and hypertension with the Status of Diabetes Mellitus type II in the Kebon Jeruk Primary health care

\begin{tabular}{|c|c|c|c|c|}
\hline & Stat & type II & & \\
\hline Variable & DM type II & Non-DM type II & p- value & PR (95\% CI) \\
\hline Family History & & & & \\
\hline Yes & $48(88.9 \%)$ & $6(11.1 \%)$ & 0.000 & 3.407 (1.702-6.823) \\
\hline No & $6(66.7 \%)$ & $17(73.9 \%)$ & & \\
\hline Age & & & & \\
\hline Risk & $38(82.6 \%)$ & $8(17.4 \%)$ & 0.008 & $1.601(1.110-2.307)$ \\
\hline No Risk & $16(51.6 \%)$ & $15(48.4 \%)$ & & \\
\hline Gender & & & & \\
\hline Male & $17(77.3 \%)$ & $5(22.7 \%)$ & 0.555 & $1.149(0.858-1.538)$ \\
\hline Female & $37(67.3 \%)$ & $18(32.7 \%)$ & & \\
\hline Physical Activity & & & & \\
\hline Less & $48(94.1 \%)$ & $3(5.9 \%)$ & 0.000 & $4.078(2.015-8.255)$ \\
\hline Enough & $6(23.1 \%)$ & $20(76.9 \%)$ & & \\
\hline Obesity & & & & \\
\hline Obesity & $26(59.1 \%)$ & $18(40.9 \%)$ & 0.028 & $0.696(0.524-0.926)$ \\
\hline Normal & $28(84.8 \%)$ & $5(15.2 \%)$ & & \\
\hline Hypertension & & & & \\
\hline Hypertension & $20(66.7 \%)$ & $10(33.3 \%)$ & 0.783 & $0.922(0.677-1.255)$ \\
\hline Non-Hypertension & $34(72.3 \%)$ & $13(27.7 \%)$ & & \\
\hline
\end{tabular}

The results to table 2, the bivariate results in the Chi-Square test indicate that there is a relationship between family history and the incidence of type II DM. With a value of $\mathrm{P}=0.000$ ( $\mathrm{p}$ value of < 0.05). Prevalence Ratio (PR) is 3.407 respondents who have a family history of type II DM at risk of 3.407 times suffer from type II DM compared with respondents who do not have a family history of suffering from DM type II. There is a relationship between age and DM type II events. With a value of $\mathrm{P}=0.008$ ( $\mathrm{p}$-value of $<0.05$ ).Prevalence Ratio $(P R)$ is 1.601 , which means respondents with age risk 1.601 times suffer from type II DM compared with the age-less respondents. There is no relationship between gender and the occurrence of type II DM.With the 
value $\mathrm{P}=0.555$ ( $\mathrm{p}$-value $>0.05$ ). Prevalence Ratio $(\mathrm{PR})$ is 1.149 , meaning that respondents with female categories have a risk of 1.149 times greater suffering from type II DM compared to males. There is a relationship between physical activity and the occurrence of DM type II.With a value of $\mathrm{P}=0.000$ ( $\mathrm{p}$-value of $<0.05$ ). Prevalence Ratio (PR) is 4.078 meaning that respondents with physical activity are less risky at 4.078 times suffer from type II DM compared with enough physical activity.

There is a relationship between obesity and type II DM occurrence. With a value of $\mathrm{P}=$ 0.028 (p-value of < 0.05).Prevalence Ratio (PR) is 0.696, meaning respondents with obesity protected 0.696 times suffer from type II DM compared with normal respondents. There is no link between the occurrence of type II DM.With a value of $\mathrm{P}=0.783$ ( $\mathrm{p}$-value of $<0.05$ ). Prevalence Ratio (PR) is 0.922 , meaning that respondents with the category of protected hypertension 0.922 times suffer from type II DM compared to respondents with the category of not hypertension.

\section{Discussion}

Based on the results of research that has been conducted to determine the description of the incidence of type II diabetes mellitus in the Kebon Jeruk primary health care, West Jakarta, the highest proportion of respondents with type II diabetes mellitus is 54 respondents $(70.1 \%)$. This research is in line with the research conducted by Prasetyani (2017) regarding the analysis of factors that affect the incidence of type II diabetes mellitus in Prolanis Puskesmas Cilacap Tengah 2, it was found that 52 people $(75.4 \%)$ had type II diabetes. The incidence of type II diabetes mellitus in the Kebon Jeruk primary health care is still relatively high due to the lack of public concern in participating in health counseling carried out by health workers either inside the health center or held outside the community health center as well as the lack of public awareness in implementing a healthy lifestyle. The use of leaflets as a health promotion medium actually has several advantages, namely: the public can see the contents or read them at leisure, can learn independently, and the information can be shared with family and friends.

Based on the results of the study obtained from 54 respondents with a family history of type II DM there are 48 respondents (88.9\%) Suffer from type II DM, while from 23 respondents with no family history DM type II There are 17 respondents (73.9\%) Does not suffer from type II DM. Family history of suffering DM becomes a risk factor for one to be exposed to Diabetes Mellitus type 2.A child is the first descendant of a DM parent (father, mother, including brother and sister). ${ }^{7}$ Statistical test results showing that there is a relationship between the family history and the incidence of type II DM. From this statistical test, we found that the value of the Prevalence odds ratio (POR) was 3.407 , with $95 \% \mathrm{CI}=1.702-6.823$. It meant that respondents who have a family history of type II DM were at risk of 3.407 times suffered from DM type II compared with respondents who do not have a family history of suffering type II DM.This research is in line with 
a study conducted by ${ }^{9}$ stating there is a relationship between family history with the occurrence of DM type II in Cengkareng West Jakarta Primary Health Care.

Diabetes mellitus tends to be lowered or inherited. Members of the family of DM people have a greater likelihood of being affected by the disease compared with family members who do not suffer from DM. ${ }^{4)}$ Although a family history of DM is a risk factor of Diabetes Mellitus type 2 that cannot be modified, it does not mean preventive efforts.To reduce the number of type II DM police officers make a preventive effort that is by conducting early detection of Diabetes mellitus disease to the community, especially for people who have a family history of suffering from DM. By knowing the family history of DM, can make one be more careful to regulate a healthy lifestyle to avoid Diabetes Mellitus type II disease. Blood sugar test is carried out in the Kebon Jeruk primary health care held almost daily, but the prevention efforts undertaken by the Primary health care have not done well because there are still many people who are reluctant to come to the Kebon Jeruk primary health care to conduct early detection. Therefore, primary health care officers are advised to conduct a blood sugar check directly or door to door, especially for people who have a family history of suffering from DM type II.

Based on the results of the study obtained from 46 respondents with age at risk, there are 38 respondents (82.6\%) Suffer from type II DM, whereas 31 respondents with age are not at risk of 16 respondents $(51.6 \%)$ Suffer from type II DM. Diabetes mellitus is one of the causes of the increasing age. Epidemiological studies with various samples, show that the increasing prevalence of Diabetes mellitus is very specific to age. ${ }^{10}$ The increasing age of a person causes the ability of the tissues to decrease in processing blood glucose. Type II DM is more common in people aged over 40 years than in younger people. ${ }^{11}$ Statistical test results showing that there is a relationship between the family history and the incidence of type II DM. From the statistical test it is also known that the value of Prevalence odds ratio (POR) is 1.601 with 95\% CI $=1.110-2.307$ meaning respondents with age are at risk of a risk of 1.601 times suffering from type II DM than respondents with age is not at risk. This research is in line with research conducted by ${ }^{12}$ stating there is a relationship between the age of DM type II events.

Based on interviews and observations conducted, respondents with age are at risk of being found more than respondents with no risk of age, this is due to older respondents there was a decrease in mitochondrial activity in muscle cells by 35\%.As a health Officer business district of Kebon Jeruk to reduce the incidence of Diabetes mellitus in the workplace Primary health care of Kebon Jeruk conducted by conducting health information dissemination related to degenerative diseases, especially diabetes mellitus through counseling held in every area of the Kebon Jeruk district, and disseminate health brochures in particular about the disease diabetes mellitus, but there are still many people who just come because they have an invitation and still many people who feel not understand the counseling given by health workers because Age factor. 
The research results show from 55 respondents with the female gender there were 37 respondents (67.3\%) Suffered from type II DM, while 22 respondents with male gender there were 17 respondents (77.3\%) Suffer from type II DM. Statistical test results showing that there is no relationship between gender and the incidence of type II DM.From this statistical test, we is found the value of the Prevalence odds ratio (POR) is 1.149 with $95 \% \mathrm{CI}=0.858-1.538$ meaning that respondents with female gender have a risk of 1.601 times suffered from DM type II compared to respondents with male gender stating that there is no relationship. This research is in line with research conducted stating that there is no meaningful link between gender and the incidence of type II diabetes.

Based on interviews and observations conducted, respondents with fewer types of DM status are found in women who do physical activity than women who do not have adequate physical activity, as many as $66.7 \%$ of women with female gender are found less physical activity due to busy work. Lack of physical activity can increase the risk of obesity that can pose a risk of diabetes mellitus, but in this study is not found a meaningful relationship between the sex with the incidence of type II diabetes, this is because both males and females have the same risk to suffer from diabetes mellitus.

Based on interviews and observations conducted, respondents with fewer types of DM status are found in women who do the physical activity than women who do not have adequate physical activity, as many as $66.7 \%$ of women with female gender are found less physical activity due to busy work. Lack of physical activity can increase the risk of obesity that can pose a risk of diabetes mellitus, but in this study is not found a meaningful relationship between the sex with the incidence of type II diabetes, this is because both males and females have the same risk to suffer from diabetes mellitus. In this study, female respondents were given soccer interventions, which showed reduced risk factors for cardiovascular and metabolic diseases. ${ }^{13}$

In this study, it was found that respondents with more physical activity compared to respondents with sufficient physical activity, this is because people who do not apply healthy lifestyle and lack of public awareness to embed the habit of a morning walk or exercise at least 15 minutes per day. Based on interviews and observations of respondents with sufficient physical activity, the majority are at risk of age for type II diabetes mellitus, and the majority are obese respondents. Therefore, the efforts undertaken by the primary health care officers are doing a healthy motion that is carried out every Wednesday and Friday as well as counseling about the importance of carrying out physical activity or exercise, but there are still many people who do not participate in the program because of lack of public awareness of its health then advised primary health care officers to be more firm in encouraging people and can increase public awareness, especially the elderly, to carry out physical activity regularly at least 15-20 minutes per day. Few prevention trials and systematic reviews provide information on potential sex or gender differences 
in diabetes prevention. ${ }^{14}$ Lifestyle changes can reduce the risk of nearly $40 \%$ after 1 and 3 years for a significant weight reduction of almost $-2.5 \mathrm{~kg}$ after three years. Therefore, the promotion of health issues is important with special attention to aspects of lifestyle changes that are more often discussed in one sex, namely healthy nutrition in men and physical activity in women. ${ }^{15,16,17,18}$

Based on the results of the study obtained from 44 respondents with a normal BMI, there are 26 respondents (59.1\%) Suffer from type II DM, while 33 respondents with obesity/overweight There are 28 respondents (84.4\%) Suffer from type II DM. Statistical results showed that there was a link between obesity and the incidence of DM type II. From this statistical test, we found the value of the Prevalence odds ratio (POR) is 0.696 with $95 \% \mathrm{CI}=0.524-0.926$, meaning that respondents with no obesity risk of 0.696 times lower suffer from type II DM compared with the respondents who are obese. This research is in line with the research conducted by ${ }^{19}$ stating that there is a significant relationship between obesity and the incidence of type II DM in primary health care in central Cilacap 2.Obesity has been found to contribute to about $55 \%$ of cases of type $2 .^{20}$ The increased level of obesity in children between the 1960s and 2000s is believed to have caused an increase in type $2 \mathrm{DM}$ in children and adolescents. ${ }^{21}$ Based on interviews and observations conducted in Kebon Jeruk primary health care respondents with obesity as a protective factor with the incidence of type II diabetes mellitus, this is due to the respondent's diet is not good or more frequent buying fast food and less activity physical/sports which are the main triggers for obesity. Therefore the health officer invites the public to do routine exercise or socalled healthy movement held by health workers every day, Wednesday and Friday, or at least once a week.

According to ${ }^{22}$ Excess weight increases the body's need for insulin. Overweight adults have greater fat cells on their body it is believed that larger fat cells do not respond well to insulin. Based on the interviews and observations conducted in the District Health center of Kebon Jeruk, respondents with obesity is obtained by respondents more obese than the respondents with obesity. This is due to the eating pattern of the respondent who is not good or more often buys ready meals as well as a lack of physical activity/exercise, which becomes the main trigger of obesity. Therefore, the health worker invites the public to do routine gymnastics or called healthy motion, that is held by health officers on Wednesday and Friday or at least 1 week. Health care officers are advised to provide health education on the importance of conducting physical activity to encourage people to apply healthy lifestyles.

Based on the results of the study obtained from 47 respondents with no hypertension, there were 34 respondents (72.3\%) Suffer from type II DM, while from 30 respondents with hypertension, there are 20 respondents (66.7\%) Suffer from type II DM. Statistical test results showed that there is no link between hypertension and the incidence of DM type II. From this statistical test, we found the value of Prevalence odds ratio (POR) is 0.922 with $95 \% \mathrm{CI}=0.677-$ 
1.255 ,meaning that respondents with hypertension have a risk of 0.922 times lower suffer from type II DM than respondents with no hypertension. This research is in line with research conducted $b^{23}$, stating that the hypertension are not at risk for the incidence of type II DM. In non-diabetic, The prevalence of hypertension was higher in males compared to females until the age of 64 years ${ }^{24}$. Insulin resistance has an important role in the development of DM and hypertension, as shown by the fact that about $50 \%$ of hypertensive patients exhibit systemic insulin resistance. ${ }^{25,26}$

Based on the interviews and observations conducted in this study, it was found that the prevalence of respondents who suffer from type II DM with smaller hypertension compared to the prevalence of respondents suffering from DM type II with no hypertension, although the results showed that the status of hypertensive respondents at the time of review showed that there were 47 respondents with no hypertension, where there are $63.0 \%$ of respondents are not hypertension in respondents with age at-risk/age above 40 years some acknowledge that they have a previous history of hypertension and as many as $37.0 \%$ of the respondents of hypertension were found atrisk age, as it has been known that the older it becomes more susceptible to pain in the decline of body endurance.

\section{Conclusion}

There is a relationship between family history, age, physical activity, and obesity with type II diabetes mellitus in Kebon Jeruk primary health care, but the gender and hypertension factor shows no relationship with the incidence of Diabetes mellitus type II in Kebon Jeruk primary health care. Lack of public awareness in conducting early detection of blood sugar, so that officers are advised to visit directly or to do the examination with door to door, especially for people who have a family history of Diabetes. Health officers are required to routinely disseminate health information related to degenerative diseases, especially diabetes mellitus, through school counseling, with health information focused on adolescent or adult women. With an outreach program focused on teenagers, youth are expected to realize the importance of health and can apply a healthy lifestyle from an early age, both in terms of consuming healthy food and routine exercise. Lack of public awareness in following a healthy motion program held by primary health care officers, so that health care officers are advised to more firmly invite the community to routinely perform healthy motion and can increase the motivation and awareness of people's importance of physical activity, for example by giving gifts to the community who diligently follow healthy motion programs and add music accompaniment so that it can contribute to the public interest.There are still many people with obesity, so health care officers are advised to give health education about the importance of doing physical activities/sports and to encourage people to apply healthy lifestyle by diligently consuming vegetables and fruits and reduce the habit of consuming ready food. 


\section{Acknowledgment}

This study was supported by research and community service institutions Universitas Esa Unggul, Indonesia.

\section{Funding}

There is no financial support from anywhere

\section{Conflict of Interest}

There is no conflict of interest

\section{References}

1. A.Y S. 5 Strategi Penderita Diabetes Mellitus Berusia Panjang. Yogyakarta: Kanisus; 2015.

2. Internasional Diabetes Federation. Guideline for Management of PostMeal Glucose in Diabetes. 2013;

3. Masriadi. Epidemiologi. Yogyakarta: Penerbit Ombak; 2012.

4. Maulana M. Mengenal Diabetes: Panduan Praktis Menangani Penyakit Kencing Manis. Yogyakarta: Katahati; 2009.

5. WHO. World Health Statistics 2015. 2015;

6. Ministry of Health of the Republic of Indonesia. Riset Kesehatan Dasar 2013. Badan Penelit dan Pengemb Kesehat Kementrian Kesehat RI.

7. Ministry of Health of the Republic of Indonesia. Riset Kesehatan Dasar 2018. Badan Penelit dan Pengemb Kesehat Kementrian Kesehat RI.

8. Puskesmas Kebun Jeruk. Health profile of Pukesmas Kebon Jeruk. 2018.

9. Trisnawati, Shara Kurnia \& Setyorogo S. Faktor Resiko Kejadian Diabetes Mellitus tipe 2 di Puskesmas Kecamatan Cengkareng Jakarta Barat. urnal Ilm Kesehat. 2013;5(1):6-11.

10. Gibney MJ. Gizi Kesehatan Masyarakat. Jakarta: EGC;

11. Suiraoka. Mengenal, Mencegah dan Mengurangi Faktor Risiko 9 Penyakit Degeneratif. Yogyakarta: Nuha Medika; 2012.

12. Fatma N. Faktor Risiko Diabetes MellitusTipe 2. 2017;

13. Krustrup P, Helge EW, Hansen PR, Aagaard P, Hagman M, Randers MB, de Sousa M MM. Effects of recreational football on women's fitness and health: adaptations and mechanisms. Eur J Appl Physiol. 2018;

14. Glechner A, Harreiter J, Gartlehner G, Rohleder S, Kautzky A, Tuomilehto J, Van Noord M, Kaminski-Hartenthaler A K-WA. Sex-specific differences in diabetes prevention: a 
systematic review and meta-analysis. Pubmed. 2015;

15. Kautzky-Willer A, Harreiter J PG. Sex and Gender Differences in Risk, Pathophysiology and Complications of Type 2 Diabetes Mellitus. Pubmed [Internet]. 2016; Available from: https://www.ncbi.nlm.nih.gov/pmc/articles/PMC4890267/

16. Wardle J, Haase AM, Steptoe A, Nillapun M, Jonwutiwes K BF. Gender differences in food choice: the contribution of health beliefs and dieting. Pubmed. 2004;

17. Kautzky-Willer A HA. Metabolic diseases and associated complications: sex and gender matter! Eur J Clin Invest. 2009;

18. Gerovasili V, Agaku IT, Vardavas CI FF. Levels of physical activity among adults 18-64 years old in 28 European countries. 2015;

19. Prasetyani Dewi AE. Karakteristik Pasien Diabetes Melitus Tipe II di Puskesmas Cilacap Tengah 1 dan 2. 2017;

20. CDC. Diabetes and Women's Health Across the Life Stages: A Public Health Perspective. U.S. Department. 2001.

21. Barlow SE and the Expert committee. Expert committee recommendations regarding the prevention, assessment and treatment of childhood and adolescent overweight and obesity: Summary report. Paediatrics. 2007;

22. Savitri R. Diabetes. Jakarta: PT Bhuana Ilmu Populer; 2008.

23. Najah S. Faktor Risiko Kejadian Diabetes Mellitus Tipe 2 pada Wanita di Puskesmas Kecamatan Pesanggrahan Jakarta Selatan. 2014;

24. Chen G, McAlister FA, Walker RL, Hemmelgarn Brenda R, Campbell Norm RC. Cardiovascular outcomes in Framingham participants with Diabetes: the importance of blood pressure. Hypertension. 2011;

25. Sowers JR, Whaley-Connell A, Hayden MR. The role of overweight and obesity in the cardiorenal syndrome. CardioRenal Med. 2011;1(1):5-12.

26. Bonora E, Capaldo B, Perin PC, Del Prato S, De Mattia G, Frittitta L, Frontoni S, Leonetti F, Luzi L, Marchesini G, Marini MA, Natali A, Paolisso G, Piatti PM, Pujia A, Solini A, Vettor R, Bonadonna RC; Group of Italian Scientists of Insulin Resistance (GISIR). Hyperinsulinemia and insulin resistance are independently associated with plasma lipids, uric acid and blood pressure in non-diabetic subjects. Nutr Metab Cardiovasc Dis. 2008; 